\title{
PENGARUH ANALISIS TEKNIKAL TERHADAP TREND PERGERAKAN HARGA SAHAM PERUSAHAAN SUBSEKTOR HOTEL DAN RESTORAN
}

\author{
Arie Pratania Putri \\ arieprataniaputri@unprimdn.ac.id \\ Mesrawati \\ Akuntansi, Fakultas Ekonomi, Universitas Prima Indonesia
}

\begin{abstract}
The hotel, restaurant, and tourism sub-sector companies are the biggest investment companies. The increased investment shows increased investor interest in buying shares. The research objective is to analyze the effect of technical analysis on the Trend of Share Price Movements in the hotel, restaurant, and tourism sub-sector companies. The technical analysis used in this research is the trading volume of the Stock, Composite Stock Price Index (CSPI) and bid-ask spread. The research population is the Hotel, Restaurant, and Tourism subsector companies listed on the Indonesia Stock Exchange. Samples were taken using a sampling technique. The sampling technique uses a purposive sampling technique. The model of data analysis uses Multiple Linear Regression Analysis. The results of the research stated that simultaneous (F-test) of the trading volume of Shares, the Composite Stock Price Index and Bid-Ask Spread have a significant effect on the stock price movement trend. Partially ( $t$-test) shows the Stock Trading Volume has a negative and significant effect on the trend of stock price movements, while the Composite Stock Price Index and Bid-ask spread do not affect the stock price movement trend.
\end{abstract}

Key words: CSPI; bid-ask spread; trading volume; stock prices

\begin{abstract}
ABSTRAK
Perusahaan sub sektor hotel, restoran dan pariwisata merupakan perusahaan yang melakukan investasi terbesar. Peningkatan investasi menunjukkan meningkatnya minat investor dalam membeli saham. Tujuan penelitian adalah untuk menganalisis pengaruh analisia teknikal terhadap Trend Pergerakan Harga Saham pada perusahaan sub sektor hotel, restoran dan pariwisata. Analisis teknikal yang digunakan dalam penelitian ini volume perdagangan Saham, Indeks Harga Saham Gabungan (IHSG) dan bid-ask spread. Populasi penelitian adalah perusahaan subsektor Hotel, Restoran dan Pariwisata yang terdaftar di Bursa Efek Indonesia. Sampel diambil dengan menggunakan teknik pengambilan sampel. Teknik pengambilan sampel menggunakan teknik purposive sampling. Model analisis data menggunakan Analisis Regresi Linear Berganda. Hasil Penelitian menyatakan bahwa secara simultan (uji-F) volume perdagangan Saham, Indeks Harga Saham Gabungan dan Bid Ask Spread berpengaruh signifikan terhadap trend pergerakan Harga Saham. Secara Parsial (uji-t) menunjukkan Volume Perdagangan Saham berpengaruh negatif dan signifikan terhadap trend pergerakan harga saham, sedangkan Indeks Harga Saham Gabungan dan Bid ask spread tidak berpengaruh terhadap trend pergerakan harga saham.
\end{abstract}

Kata kunci: IHSG; bid ask spread; volume perdagangan; harga saham.

\section{PENDAHULUAN}

Peningkatan investasi di perusahaan yang terdaftar di Bursa Efek Indonesia sejalan dengan peningkatan pertumbuhan ekonomi. Investasi yang meningkat mengindikasikan bahwa pasar modal aktif dalam melakukan perdagangan saham. Perdagangan saham yang aktif ditandai dengan banyaknya permintaan dan penawaran atas saham yang diperjualbelikan. Saham yang di perjualbelikan memberikan dampak pada terjadinya fluktuasi harga saham. 
Kondisi fluktuasi harga saham dapat di sebabkan beberapa faktor diantaranya manipulasi pasar dan adanya rumor. Manipulasi pasar terjadi ketika investor menggunakan media massa untuk kepentingannya. Manipulasi pasar dengan memberikan isu-isu yang terkait dengan kondisi perusahaan yang menyebabkan kenaikan atau penurunan harga saham.

Fluktuasi harga saham terjadi karena adanya kekuatan penawaran atas saham, Jika semakin banyak penawaran atas saham maka harga saham akan turun. semakin banyaknya jumlah permintaan atas saham maka harga saham akan naik.

Penelitian yang berkaitan dengan analisis teknikal sangat banyak. Beberapa hasil penelitian sejalan dengan teori dan ada yang tidak konsisten.

Abidin, et al. (2016) dengan judul Pengaruh Faktor-Faktor Teknikal Terhadap Harga Saham (Studi Pada Harga Saham IDX30 di Bursa Efek Indonesia Periode Tahun 2012-2015). Penelitian ini mengambil variabel penelitian Bid Volume, Harga Saham Masa Lalu, dan volume perdagangan. Hasil penelitian menjelaskan bahwa volume bid tidak berpengaruh terhadap harga saham yang disebabkan banyak nya investasi menyebabkan pergerakan volume bid terjadi dengan cepat sehingga tidak berpengaruh terhadap harga saham.

Keseimbangan pasar dalam bursa ditentukan oleh pergerakan volume bid dan volume ask yang berubah secara cepat karena banyaknya investor (pembeli dan penjual) di bursa dan tingginya variasi ekspektasi antara investor satu dengan lainnya. Namun, ketika permintaan dan penawaran atas saham berubah tidak akan mempengaruhi pergerakan harga saham itu sendiri. Volume perdagangan mempengaruhi trend pergerakan saham. Volume perdagangan saham dapat menggambarkan kondisi efek yang diperjualbelikan di pasar modal. Peningkatan volume perdagangan mencerminkan meningkatnya jumlah permintaan dan penawaran pada suatu saham. Volume perdagangan juga merupakan salah satu faktor yang memberikan pengaruh terhadap pergerakan saham.

Penelitian lainnya yang dilakukan Samsuar dan Akramunnas (2017) yang meneliti variabel analisis teknikal dari segi indeks harga saham gabungan dan volume perdagangan. Hasil penelitian menunjukkan bahwa volume perdagangan berpengaruh terhadap harga saham. Indeks harga saham gabungan tidak berpengaruh terhadap harga saham.

Hasil penelitian yang dilakukan Sandrasari (2010) yang meneliti volume perdagangan, dimana hasil penelitiannya menunjukkan variabel volume perdagangan berpengaruh positif dan signifikan terhadap volatilitas (kecepatan pergerakan) harga saham. Ekspektasi dan opini trader akan tercermin dalam volume perdagangan yang dapat menggerakkan harga. Semakin banyak jumlah lot saham yang berhasil diperjualbelikan dalam satu hari maka pergerakan harga saham juga akan semakin fluktuatif.

Penelitian Wulandari, et al. (2009), hasil penelitian nya menjelaskan bahwa volume perdagangan tidak berpengaruh terhadap harga saham. Penelitian Rahayu (2017) yang berjudul analisis teknikal harga saham pada perusahaan farmasi yang terdaftar di Bursa Efek Indonesia Periode 2015. Salah satu Variabel yang diteliti adalah volume perdagangan. Hasil penelitian nya menunjukkan bahwa volume perdagangan tidak berpengaruh terhadap harga saham. Penelitian yang dilakukan Parulian, et al. (2013) yang meneliti variabel indeks harga saham gabungan terhadap fluktuasi harga saham. Hasil penelitian menyatakan bahwa indeks harga saham gabungan berpengaruh terhadap fluktuasi harga saham.

Petumbuhan ekonomi di Indonesia mengalami peningkatan investasi yang cukup pesat. Salah satu perusahaan yang mengalami dampak pertumbuhan ekonomi adalah perusahaan sub sektor hotel, restoran dan pariwisata. Dikutip dari Antara news, ditahun 2013 investasi terbesar di Indonesia adalah bidang hotel dan restoran. 
Ditahun tersebut, investasi sektor pariwisata mencapai 602,648 juta dolar AS dalam bentuk Penanaman Modal Asing. (Antara News, 2014).

Perusahaan subsektor hotel, restoran dan pariwisata berkembang sangat pesat. Dibeberapa tahun Dilihat dari Nilai realisasi investasi di 10 Destinasi Pariwisata Prioritas mencapai 28,51 triliun rupiah atau sekitar 42,5 persen dari total realisasi investasi sektor pariwisata pada kurun waktu tahun 2015 sampai semester I/2018.

Investasi merupakan aktivitas yang memanfaatkan dananya pada saat sekarang dengan harapan akan mendapatkan keuntungan dimasa yang akan datang. Pasar modal merupakan tempat penghubung antara para investor dengan perusahaan melalui perdagangan saham, obligasi dan lainnya. Dalam melakukan investasi, investor harus dapat memahami mengenai kondisi dan peluang dalam berinvestasi. Investor sebagai pihak yang akan melakukan investasi dipasar Modal mempunyai berbagai pertimbangan-pertimbangan khusus. Informasi yang akurat diperlukan untuk mengetahui sejauh mana faktorfaktor yang menjadi penyebab fluktuasi harga saham perusahaan yang akan dibeli. Dengan mengetahu faktor-faktor tersebut investor akan dapat memilih strategi untuk memilih perusahaan yang benar-benar dianggap sehat sebagai tempat berinvestasi, (Wulandari, et al., 2009). Faktor-faktor yang mempengaruhi harga saham berasal dari faktor eksternal maupun faktor internal.

Analisis teknikal dan analisis fundamental dapat digunakan umtuk membantu investor dalam melihat trend pergerakan harga saham. Analisis fundamental lebih memfokuskan kepada kinerja perusahaan dari lingkungan internal dan lingkungan eksternal berfokus pada kondisi perekonomian. Analisis teknikal adalah analisis untuk memprediksi pergerakan harga saham. Menurut Ong (2016:1) analisis teknikal merupakan metode pengevaluasian saham ataupun sekuritas, dengan dianalisis secara statistik yang datanya diperoleh dari analisis pasar dimasa lampau dengan tujuan dapat memprediksi harga saham dimasa mendatang. Faktor-Faktor analisis teknikal dalam penelitian misalnya volume perdagangan saham, Indeks Harga Saham Gabungan dan bid ask spread. Analisis teknikal membantu investor dalam pengambilan keputusan untuk berinvestasi. Tujuan investor menginvestasikan dananya pada saham tentunya akan mendapatkan keuntungan. Keuntungan yang diperoleh akan diiringi dengan risiko yang diterima. Semakin besar keuntungan yang diterima investor, risiko yang diterima juga semakin besar sesuai dengan hukum high risk-high return, low risk low return.

Investor perlu melakukan penilaian terhadap saham yang akan dibeli dan keuntungan yang akan diperoleh dari membeli saham tersebut. Saham merupakan pilihan investasi yang sangat cepat mengalami perubahan terhadap suatu informasi yang berkembang. Saham adalah bukti kepemilikan didalam perusahaan. Ketika investor berinvestasi dapat membeli saham yang diterbitkan perusahaan. Penilaian saham dinilai dari 3 jenis, yaitu nilai buku, nilai pasar dan nilai intristik. Nilai perusahaan dapat mencerminkan harga saham perusahaan. Apabila harga saham suatu perusahaan meningkat maka investor akam menganggap nilai perusahaan juga akan baik dan sebaliknya.

Investor memerlukan analisis teknikal dalam pengambilan keputusan berinvestasi yang berbentuk saham. Analisis teknikal disebut sebagai analisis yang menggunakan data historis dengan melihat harga saham dimasa lalu dalam peramalannya. Dari pergerakan harga tersebut investor dapat mengamati pergerakan kenaikan ataupum penurunan harga saham yang tujuannya untuk pengambilan keputusan untuk membeli atau menjual saham. Investor selalu dihadapkan dengan pilihan untuk memutuskan menjual atau membeli saham. Keputusan yang diambil investor harus dibuat dengan hati-hati supaya tidak menimbulkan kerugian bagi imvestor atau berdampak 
penurunan return yang akan diterima. Dalam Utomo (2016: 90) trend pergerakan harga saham ada 3 yaitu: trend naik, trend turun dan trend mendatar. Trend naik adalah kondisi pergerakan harga yang ditandai dengan munculnya titik terendah baru yang terus mengalami kenaikan dan juga titik tertinggi baru yang juga terus mengalami kenaikan selama periode tertentu. Trend turun adalah kondsi yang terjadi menunjukkan harga terus mencatat titik tertinggi yang semakin lama semakin rendah dan titik terendah yang terus menurun. Trend mendatar, harga bukannya bergerak pada satu arah selama beberapa waktu, tetapi bergerak sementara pada kisaran harga tertentu dalam suatu periode.

Pergerakan harga saham yang terjadi dipengaruhi berbagai faktor, baik rasional maupun irasional namun pada akhirnya semua akan tercermin pada supply dan demand. Jika harga saham naik, permintaan (demand) pasti lebih besar daripada penawaran (supply), sebaliknya jika harga saham turun maka supply lebih besar daripada demand (Ong, 2016: 2). Prinsip dasar dari analisis teknikal adalah pergerakan harga yang terjadi dipasar, terdapat pula kecenderungan dalam pergerakan harga saham.

Volume Perdagangan saham merupakan banyaknya jumlah lembar saham yang diperdagangkan dengan harga yang telah disepakati setiap harinya oleh pihak pembeli mapun penjual di broker perdagangan saham. Volume perdagangan saham dapat mencerminkan transaksi perdagangan saham, dimana jika semakin tinggi volume perdagangan saham maka akan berdampak pada kenaikan harga saham.

Indeks harga saham gabungan (IHSG) mencerminkan keadaan investasi disuatu negara, jika indeks harga saham gabungan naik maka mencerminkan kenaikan investasi dan sebaliknya jika indeks harga saham gabungan turun mencerminkan investasi menurun atau dalam kondisi tidak baik, yang akan berdampak pada harga saham akan turun. Bid ask spread mencerminkan nilai jual dan nilai beli saham, dimana askbid spread merupakan selisih dari harga beli dikurangi dengan harga jual saham. Bid ask spread tergantung dari permintaan dan penawaran pasar.

Dari beberapa penelitian terdahulu yang hasil penelitian menjelaskan adanya pengaruh maupun tidak berpengaruh, peneliti merasa tertarik untuk meneliti kembali dengan judul pengaruh analisa teknikal terhadap trend pergerakan harga saham.

Rumusan masalah dalam penelitian adalah: 1). Bagaimana pengaruh volume perdagangan terhadap trend pergerakan harga saham? 2). Bagaimana pengaruh indeks harga saham gabungan terhadap trend pergerakan harga saham? 3). Bagaimana pengaruh bid ask spread terhadap trend pergerakan harga saham? 4). Bagaimana pengaruh volume perdagangan, indeks harga saham gabungan dan Bid-Ask Spread berpengaruh terhadap Trend Pergerakan Harga Saham pada perusahaan subsektor Hotel, Restoran dan Pariwisata?

Tujuan Penelitian dalam penelitian adalah untuk mengetahui dan menganalisis pengaruh volume perdagangan saham, indeks harga saham gabungan, dan bid ask spread terhadap trend pergerakan harga saham.

\section{TINJAUAN TEORETIS \\ Teori Pasar Efisiensi}

Suatu Pasar dikatakan efisien apabila tidak seorangpun, baik dari investor individu maupun investor institusi akan mampu memperoleh return tidak normal (abnormal return), setelah disesuaikan dengan risiko, dengan menggunakan strategi perdagangan yang ada. Artinya harga-harga yang terbentuk dipasar merupakan cerminan dari informasi yang ada.

\section{Analisis Teknikal}

Analisis teknikal merupakan metode analisis untuk membaca pergerakan harga dengan menggunakan data historis berupa kombinasi nilai harga pembukaan dan penutupan serta harga tertinggi saham dan 
terendah saham" (May (2011:38). Menurut Utomo (2016:40) Analisis teknikal adalah sebagai alat untuk memprediksi pergerakan harga dengan tujuan untuk memperkirakan arah pergerakan harga saham dimasa yang akan datang. Harga Saham dapat ditentukan dari jumlah Permintaan dan penawaran saham (Halim, 2015: 11). Analisis teknikal juga mempertimbangkan pergerakan harga saham saja tanpa memperhatikan kinerja perusahaan yang mengeluarkan saham tersebut.

Analisis teknikal menyajikan informasi yang memberikan gambaran kepada investor untuk menentukan pada saat kapan melakukan pembelian dan kapan menjual saham tersebut untuk memperoleh keuntungan yang maksimal. Analisis teknikal mencerminkan informasi yang relevan dan informasi tersebut mencerminkan perubahan harga saham dari masa lalu. Santoso dan Muazaroh (2018) Analisis Teknikal menjelaskan perubahan harga saham tanpa melihat perubahan kinerja perusahaan.

\section{Harga Saham}

Harga saham merupakan nilai sekarang yang akan diterima oleh pemilik saham dikemudian hari. interaksi hubungan antara penjual dan pembeli dengan megharapkan profit perusahaan akan membentuk harga saham. Investor dapat menganalisis terhadap pembentukan harga saham dan dapat mengambil keputusan untuk menjual maupun membeli saham. Menurut Buwono (2007) dalam Zulkarnaen (2017) pembentukan harga saham dipasar modal dibagi menjadi dua yaitu pasar reguler dan pasar negoisasi. Pasar reguler pembentukan harga saham dengan cara tawar menawar sesuai dengan kekuatan pasar, sedangkan pasar negoisasi harga saham terbentuk dengan cara negoisasi antara penjual dan pembeli. Hidayat (2010:103), harga saham terdiri dari harga nominal, harga pembuka (opening price), harga pasar (market price) dan harga penutupan (closing price). Harga yang ditetapkan pada saat pasar saham sedang berlangsungdengan mempertimbangkan per- mintaan dan penawarandari saham yang dimaksud adakah harga saham (Jogiyanto, 2015). Fluktuasi harga saham ditentukan berdasarkan penilaian investor terhadap perusahaan. Apabila perusahaan dipandang memiliki masa depan yang baik, dan diperkirakan akan berkembang pesat, maka investor tersebut memberikan penilaian yang tinggi terhadap saham perusahaan yang sedang dipertukarkan, demikian pula sebaliknya (Aprilia, 2015).

Menurut Arifin; (2004) dalam Akhmadi dan Prasteyo (2018) beberapa faktor yang mempengaruhi harga saham suatu bursa yakni: 1). Kondisi fundamental emiten berhubungan dengan kondisi keuangan, strategi bisnis, produksinya, manajemen, dan rasio keuangan, 2). Hukum permintaan dan penawaran berkaitan dengan kenaikan harga karena permintaan yang banyak atau penawaran yang sedikit tidak akan berlangsung terus sebab pada suatu titik harga saham akan menjadi lebih mahal, 3). Tingkat suku bunga (SBI) berkaitan dengan perubahan suku bunga, tingkat pengembalian investasi akan mengalami perubahan, ada yang cenderung naik dan ada yang cenderung turun. 4). Valuta asing, dalam menghadapi perekonomian global, tidak ada satupun negara didunia yang dapat menghindari perekonomiannya dari pengaruh valuta asing khususnya dolar Amerika, 5). Dana asing di bursa, jika suatu bursa dikuasai oleh investor asing maka ke cenderungan saham sedikit tergantung dari investor asing. Indeks Harga Saham Gabungan (IHSG), mencerminkan kondisi keseluruhan bursa saham jika dibandingkan menjadi ukuran kenaikan maupun penurunan harga saham. 6). News dan Rumors, adalah semua berita yang terjadi ditengah masyarakat yang menyangkut mengenai ekonomi, sosial dan politik.

Menurut Osmad (2007) dalam Adwiyah (2014) variabel teknikal yang mempengaruhi harga saham adalah sebagai berikut: 1). Volume Penjualan saham, merupakan rasio jumlah embar saham yang diperdagangkan dibagi jumlah saham yang beredar. 2). 
Harga saham masa lalu merupakan upaya yang memperkirakan harga saham dengan mengamati perubahan harga saham dimasa lalu yaitu tahun sebelumnya.

\section{Indikator Harga Saham dilihat dari Closing} Price.

\section{Volume Perdagangan Saham}

Volume perdagangan saham merupakan perbandingan jumlah lembar saham yang diperdagangkan pada waktu tertentu terhadap jumlah lembar saham yang beredar pada waktu tertentu, (Husnan, 2005 dalam Arifanisa dan Nugraha (2017). Volume perdagangan saham adalah jumlah lembar saham dari suatu emiten atau perusahaan yang diperjualbelikan dibursa efek setiap harinya sesuai dengan harga yang telah disepakati oleh pihak penjual dan pihak pembeli melalui perantara (broker). Penjualan saham yang dilakukan perusahaan berasal dari Jumlah lembar saham yang diterbitkan. Tingkat penjualan saham nantinya akan menunjukkan prestasi manajemen yang bersifat operasional dalam menghasilkan penjualan.

Indriastuti dan Nafiah (2017) Volume Perdagangan adalah salah satu indikator likuiditas saham atau berupa informasi yang ada di pasar modal. Kondisi pasar bursa yang bagus ditunjukkan oleh volume perdagangan yang tinggi.

Indikator Volume Perdagangan $=\frac{\text { Jumlah saham yang diperdagangkan }}{\text { jumlah lembar saham yang beredar }}$

\section{Indeks Harga Saham Gabungan}

Indeks harga saham gabungan (IHSG) menunjukkan pergerakan harga saham secara umum yang tercatat di bursa efek. Indeks ini sebagai acuan tentang perkembangan kegiatan di pasar modal. IHSG ini bisa untuk menilai situasi pasar secara umum atau mengukur apakah harga saham mengalami kenaikan atau penurunan. Mie dan Agustina (2014) Indeks Harga saham gabungan (IHSG) diperkenalkan pertama kali pada tanggal 1 April 1984 sebagai indikator dalam memantau pergerakan saham. Hari dasar Perhitungan Indeks adalah tanggal 10 Agustus 1982 dengan nilai 100. Sedangkan Jumlah Emiten yang tercatat pada waktu itu sebanyak 13 emiten.

Indeks Harga Saham Gabungan (IHSG) menunjukkan perhitungan dari harga seluruh saham yang tercatat dengan dipengaruhi besarnya nilai kapitalisasi pasar suatu saham. Nilai kapitalisasi pasar itu sendiri adalah nilai seluruh saham yang dihitung berdasarkan harga yang terakhir, dan nilai dasar adalah merupakan nilai yang dihitung berdasarkan harga perdana masing-masing saham. (Thian, 2001 dalam Kasim, 2010).

Indeks Harga Saham Gabungan dihitung setiap hari atau setiap detik selama jam perdagangan. Indeks Harga Saham Gabungan berubah setiap hari karena (1) perubahan harga pasar yang terjadi setiap hari dan (2) adanya saham tambahan

\section{Bid Ask Spread}

Dalam pasar modal, seorang investor ketika melakukan Perdagangan saham mengalami kesulitan dalam menjual dan membeli sesuai dengan harga dan jumlah yang diinginkan. Investor memerlukan waktu cukup lama dalam mencapai keinginan pada tingkat harga pasar.

Darmadji dan Fakruddin (2001) dalam Anwar dan Asandimitra (2014), Bid merupakan harga yang diajukan oleh pihak yang akan melakukan pembelian saham, sedangkan ask menunjukkan harga yang ditawarkan oleh pihak yang akan menjual saham tersebut. Bid adalah harga dimana pembeli bersedia membeli saham, sedangkan ask adalah harga diamana penjual bersedia menerima untuk suatu saham. Spread adalah selisih dari harga jual dengan harga beli. Agar terjadi suatu transaksi (matched), maka pihak pembeli (pihak yang melakukan bid) dapat meningkatkan bid-nya atau pihak penjual (pihak yang melakukan ask) menurunkan tawarannya. Saat ingin membeli atau menjual sejumlah saham investor harus menunggu atau jika spread antara 
penawaran dan permintaan terlalu besar akan mempengaruhi harga pasar secara substansial yang artinya saham tersebut tidak likuid.

Indikator Bid Ask Spread:

Dimana:

$$
\text { bid ask spread }=\frac{\text { ask it }- \text { bid it }}{(\text { ask } i t+\text { bit } i t) / 2}
$$

Bid it = harga minat beli saham i pada penutupan periode $t$.

Askit/offer it = harga minat jual saham i pada penutupan periode

Pengaruh Volume Perdagangan Saham terhadap Trend Pergerakan Harga Saham

Menurut Lestari (2014), jumlah saham yang diperdagangkan di bursa pada suatu waktu merupakan volume perdagangan saham. Susanto dan Sabardi (2010) menyatakan bahwa secara historis volume perdagangan saham mempunyai kaitan dengan harga pasar di bursa, dikarenakan volume perdagangan saham dianggap sebagai ukuran dari kekuatan atau kelemahan pasar sesuai dengan hukum permintaan dan penawaran. Peningkatan volume perdagangan saham dapat menambah informasi yang berguna bagi investor secara kontinyu dalam periode perdagangan dimana saat volume perdagangan saham dalam jumlah kecil yang menyebabkan harga jatuh. Semakin tinggi minat atau permintaan saham, semakin mendorong kenaikan harga saham". (Darwis, 2013), perdagangan saham yang aktif, yaitu dengan volume perdagangan yang besar menunjukkan bahwa saham tersebut digemari oleh investor. Volume perdagangan saham dipengaruhi oleh informasi yang diterima investor. Apabila tidak ada informasi mengenai saham, maka investor akan tetap menahan saham mereka yang menyebabkan volume perdagangan saham menjadi turun, yang berdampak tidak banyak saham yang dijual yang mengakibatkan fluktuasi pergerakan saham (Dewi dan Siaryana, 2016).
Besarnya volume perdagangan saham diketahui dengan mengamati volume perdagangan saham. Semakin likuid saham ditentukan besarnya volume perdagangan saham yang mengindikasikan bahwa saham diminati oleh investor sehingga akan aktif diperdagangkan. Bidiosta, et al. (2015) menyatakan bahwa volume perdagangan saham memiliki pengaruh signifikan terhadap harga saham (Nilai perusahaan).

$H_{1}$ : Volume Perdagangan Saham berpengaruh terhadap trend pergerakan harga saham

\section{Pengaruh Indeks Harga Saham Gabungan (IHSG) terhadap trend pergerakan harga saham}

Indeks Harga Saham Gabungan merupakan representasi dari capital flow dan gairah pasar yang, mencerminkan keuntungan dan kerugian perdagangan oleh investor. Indeks Harga saham gabungan merupakan kondisi keseluruhan bursa saham yang terjadi jika dibandingkan menjadi ukuran kenaikan maupun penurunan harga saham. Menurut Jogiyanto (2013:147), Indeks Harga Saham Gabungan (IHSG) merupakan angka indeks harga saham yang sudah disusun dan dihitung dengan menghasilkan trend, dimana angka indeks adalah angka yang diolah sedemikan rupa sehingga dapat digunakan untuk membandingkan kejadian yang dapat berupa perubahan harga saham dari dari waktu ke waktu

Indeks Harga Saham Gabungan yang mengalami kenaikan sepanjang waktu tertentu, tentunya akan menggambarkan kondisi investasi dan perekonomian negara dalam keadaan baik.

Sebaliknya jika turun Indeks Harga Saham Gabungan menggambarkan iklim investasi sedang buruk. Kondisi demikian akan mempengaruhi naik atau turunnya harga saham di pasar bursa. (Samsuar dan Akrammunnas, 2017).

$\mathrm{H}_{2}$ : Indeks Harga Saham Gabungan berpengaruh terhadap Trend pergerakan Harga saham 


\section{Pengaruh Bid Ask Spread terhadap Trend Pergerakan Harga Saham}

Bid adalah harga ketika pembeli bersedia membayar untuk suatu saham, sedangkan ask adalah harga ketika penjual bersedia menerima untuk suatu saham. Rumus Bid-Ask Spread adalah Selisih dari harga jual dan harga beli suatu saham yang diperdagangkan.

Tingkat likuiditas saham dpengaruhi oleh perbedaan harga jual (ask price) dan harga beli (bid price). Saham yang diperdagangkan adalah saham yang likuid nilainya. Tingkat likuiditas saham dapat dilihat dari selisih harga jual (ask price) terendah dan harga beli (bid price) tertinggi atau juga disebut dengan bid-ask price. Semakin kecil selisih (spread) harga saham, maka semakin likuid saham tersebut, maka akan meningkatkan harga saham, dimana saham yang likuid akan diminati oleh pasar.

Bid Ask Spread yang rendah mengindikasikan harga saham tinggi yang mencerminkan bahwa perusahaan dalam kondisi baik. Kanaikan maupun penurunan harga saham bukan hanya disebabkan perubahan penawaran dan permintaan yang terjadi tetapi juga karena adanya penilaian investor.

Bid ask spread yang tinggi mengindikasikan keuntungan yang besar, namun bid ask spread yang terlalu tinggi akan mengakibatkan saham tersebut kurang aktif diperdagangkan. Bid ask spread yang terlalu rendah akan mengindikasikan keuntungan yang lebih rendah, namun bid ask spread yang rendah akan mengakibatkan saham tersebut menjadi aktif diperdagangkan (Perdana dan Kristanti, 2014).

$H_{3}$ : Bid-Ask spread berpengaruh terhadap trend pergerakan harga saham

Pengaruh volume perdagangan, Indeks Harga Saham Gabungan dan Bid Ask Spread secara simultan terhadap trend pergerakan harga saham

Volume perdagangan saham yang besar, indeks harga saham gabungan yang aktif, mengindikasikan adanya fluktuasi pergerakan harga saham. Saham-saham yang aktif diperdagangkan mengindikasikan permintaan akan saham naik, dimana ketika permintaan saham naik menunjukkan pergerakan harga saham cenderung naik. Ketika bid ask spread semakin kecil selisih dari harga jual dengan harga beli menunjukkan harga saham menigkat.

$H_{4}$ : Volume perdagangan, IHSG dan bidask spread berpengaruh secara simultan terhadap trend pergerakan harga saham

\section{Rerangka Konseptual}

Dalam penelitian ini kerangka konseptual menunjukkan pengaruh volume perdagangan saham berpengaruh terhadap trend pergerakan harga saham, indeks harga saham gabungan berpengaruh terhadap trend pergerakan harga saham dan pengaruh bid ask spread terhadap trend pergerakan harga saham. Rerangka konseptual dapat dilihat pada Gambar 1.

\section{Penelitian Terdahulu}

Penelitian Terdahulu dalam penelitian ini adalah: Abidin, et al. (2016) dengan judul Pengaruh Faktor-faktor Teknikal terhadap Harga Saham (Studi Pada Harga Saham IDX30 di Bursa Efek Indonesia Periode Tahun 2012-2015). Variabel dalam penelitian Bid Volume, Harga saham masa lalu, volume perdagangan dan harga saham. Hasil penelitian menjelaskan bahwa volume bid, Volume perdagangan, harga saham masa lalu berpengaruh secara simultan terhadap harga saham.

Volume perdagangan dan harga saham masa lalu berpengaruh terhadap harga saham sedangkan volume bid tidak berpengaruh terhadap harga saham. Samsuar dan Akramunnas (2017) dengan judul Pengaruh Faktor fundamental dan teknikal terhadap harga saham industri perhotelan yang terdaftar di Bursa Efek Indonesia. Variabel dalam penelitian ini Harga saham, ROA, CR, IHSG dan Volume Perdagangan. Hasil penelitian untuk faktor teknikal menyatakan bahwa IHSG berpengaruh positif 



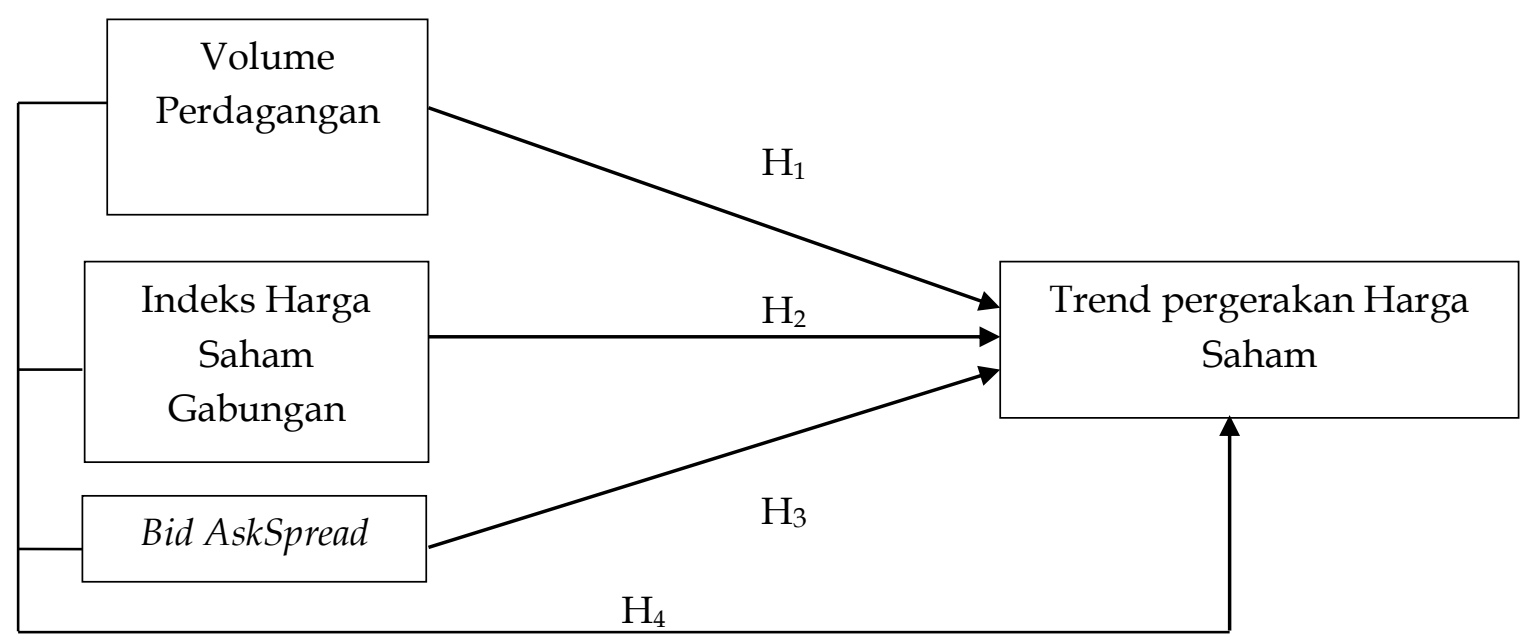

Gambar 1

Rerangka Konseptual

dan tidak signifikan terhadap harga saham. Volume perdagangan berpengaruh positif terhadap harga saham. Santoso (2018) dengan judul pengaruh frekuensi perdagangan, harga saham masa lalu dan volume perdagangan terhadap harga saham IDX30. Variabel penelitian frekuensi perdagangan, harga saham masa lalu dan volume perdagangan. Hasil penelitian menyatakan bahwa frekuensi perdagangan dan harga saham masa lalu secara parsial berpengaruh terhadap harga saham, sedangkan volume perdagangan tidak berpengaruh terhadap harga saham.

\section{METODE PENELITIAN}

Metode Penelitian adalah penelitian ekspalanatory. Penelitian eksplanatory adalah penelitian yang menjelaskan antar variabel. Pendekatan penelitian yang dilakukan adalah penelitian kuantitatif. Jenis penelitian yang digunakan adalah hubungan kausal, yaitu hubungan yang bersifat sebab akibat.

Jenis dan sumber data dalam penelitian menggunakan data sekunder, yaitu data mengenai volume perdagangan, indeks harga saham gabungan, nilai bid, dan ask serta harga saham, data diambil di website www.idx.co.id dan http://finance. yahoo. com

\section{Populasi dan Sampel}

Populasi dalam penelitian adalah Perusahaan Sub Sektor Hotel, Restoran dan Pariwisata yang terdaftar di Bursa Efek Indonesia tahun 2015-2017. Teknik pengambilan sampel adalah teknik purposive sampling.

Kriteria pengambilan sampel dalam penelitian ini sebagai berikut: 1). Perusahaan sub sektor hotel, restoran dan pariwisata yang terdaftar di Bursa Efek Indonesia tahun 2015-2017, 2). Perusahaan subsektor hotel, restoran dan pariwisata yang listing tahun 2015-2017, 3). Perusahaan yang melakukan perdagangan saham tahun 20152017.

Berdasarkan kriteria sampel dari 25 populasi penelitian maka sampel dipilih sebanyak 19 sampel yang memenuhi syarat untuk dijadikan sampel dalam peneltian.

Tabel 1

Kriteria Pengambilan Sampel

\begin{tabular}{clc}
\hline No & Keterangan & Jumlah \\
\hline 1 & Perusahaan Sub Sektor & \\
& Hotel, Restoran dan Pari- & \\
& wisata yang terdaftar di & 25 \\
& Bursa Efek Indonesia & \\
& Tahun 2015-2017 \\
\hline
\end{tabular}




\begin{tabular}{lll}
\hline 2 & $\begin{array}{l}\text { Perusahaan Sub Sektor } \\
\text { Hotel, Restoran dan Pari- }\end{array}$ & \\
& wisata yang delisting \\
ditahun 2015-2017 & \\
\hline $3 \quad$ & $\begin{array}{l}\text { Perusahan subsektor ho- } \\
\text { tel, restoran dan pari- }\end{array}$ \\
& wisata yang tidak me- & 1 \\
& lakukan perdagangan \\
& saham ditahun 2015-2017 & \\
\hline & Sampel & 19 \\
\hline
\end{tabular}

Tabel 2

Daftar Sampel

\begin{tabular}{|c|c|c|}
\hline No & $\begin{array}{l}\text { Kode } \\
\text { Emitem }\end{array}$ & Nama perusahaan \\
\hline 1 & BAYU & Bayu Buana Tbk \\
\hline 2 & BUVA & Bukit Uluwatu Villa Tbk. \\
\hline 3 & FAST & Fast Food Indonesia Tbk. \\
\hline 4 & HOME & $\begin{array}{l}\text { Hotel Mandarine } \\
\text { Regency Tbk. }\end{array}$ \\
\hline 5 & HOTL & $\begin{array}{l}\text { Saraswati Griya Lestari } \\
\text { Tbk. }\end{array}$ \\
\hline 6 & ICON & $\begin{array}{l}\text { Island Concepts } \\
\text { Indonesia Tbk. }\end{array}$ \\
\hline 7 & INPP & $\begin{array}{l}\text { Indonesian Paradise } \\
\text { Property Tbk. }\end{array}$ \\
\hline 8 & JIHD & $\begin{array}{l}\text { Jakarta International } \\
\text { Hotels \& Development } \\
\text { Tbk. }\end{array}$ \\
\hline 9 & KPIG & MNC Land Tbk. \\
\hline 10 & MAMI & $\begin{array}{l}\text { Mas Murni Indonesia } \\
\text { Tbk }\end{array}$ \\
\hline 11 & PDES & $\begin{array}{l}\text { Destinasi Tirta } \\
\text { Nusantara Tbk }\end{array}$ \\
\hline 12 & PGLI & $\begin{array}{l}\text { Pembangunan Graha } \\
\text { Lestari Indah Tbk. }\end{array}$ \\
\hline 13 & PTSP & $\begin{array}{l}\text { Pioneerindo Gourmet } \\
\text { International Tbk. }\end{array}$ \\
\hline 14 & PUDP & Pudjiadi Prestige Tbk. \\
\hline 15 & PJAA & $\begin{array}{l}\text { Pembangunan Jaya } \\
\text { Ancol Tbk. }\end{array}$ \\
\hline 16 & PNSE & Pudjiadi dan Sons Tbk. \\
\hline 17 & PANR & $\begin{array}{l}\text { Panorama Sentrawisata } \\
\text { Tbk. }\end{array}$ \\
\hline 18 & PSKT & Red Planet \\
\hline 19 & SHID & Hotel Sahid Jakarta \\
\hline
\end{tabular}

\section{Teknik Pengumpulan Data}

Teknik pengumpulan data dalam penelitian ini menggunakan studi kepustakaan dan studi internet. Data yang digunakan adalah data sekunder. Data yang digunakan berupa data harga saham, volume perdagangan saham, serta harga jual dan harga beli saham dan data indeks harga saham gabungan.

\section{Analisis data}

Model analisis data dalam penelitian menggunakan analisis regresi linear berganda. Analisis regresi Linear Berganda digunakan karena variabel independen yang digunakan lebih dari 1 variabel independen. Analisis ini menggunakan software SPSS. Persamaan Regresi dalam penelitian ini sebagai berikut:

$$
Y=a+b_{1} x_{1}+b_{2} x_{2}+b_{3} x_{3}+e
$$

Dimana:

$$
\begin{aligned}
\mathrm{Y}= & \text { Trend pergerakan Harga Saham } \\
\mathrm{a}= & \text { konstanta } \mathrm{b}_{1}, \mathrm{~b}_{2}, \mathrm{~b}_{3}=\text { koefisen regresi } \\
\mathrm{X}_{1}= & \text { Volume Perdagangan Saham } \\
\mathrm{X}_{2}= & \text { Indeks Harga Saham Gabungan } \\
& \text { (IHSG) } \\
\mathrm{X}_{3}= & \text { Bid-ask spread } \\
\mathrm{e}= & \text { error }
\end{aligned}
$$

\section{Uji Asumsi Klasik}

Penelitian ini menggunakan Uji asumsi klasik. Uji asusmsi klasik bertujuan untuk mengetahui kelayakan penggunaan model regresi dalam penelitian.

Uji asumsi klasik yang terdiri dari:

1. Uji Normalitas, yang digunakan dalam penelitian ini adalah one sample kolmogrov smirnov dan grafik p-plot. Uji normalitas dilakukan untuk melihat data penelitian berdistribusi normal.

2. Uji heterokskedastisitas, untuk melihat tidak terjadi heteroskedastisitas menggunakan uji glejser dan scaterplot. Nilai signifikan untuk uji glejser $>$ 0,05 maka tidak terjadi heteroskedastisitas, dan untuk scaterplot titik-titik menyebar tidak membentuk suatu pola. 
3. Uji multikolinieritas, Multikolinearitas merupakan suatu keadaan dimana terjadinya satu atau lebih variabel bebas yang berkorelasi sempurna atau mendekati sempurna dengan variabel bebas lainnya.

4. Uji Autokorelasi menggunakan Run Test. Autokorelasi tidak terjadi jika nilai Signifikan $>0,05$.

\section{Koefisien Determinasi}

Koefisien determinasi $\left(R^{2}\right)$ bertujuan mengukur kemampuan model dalam menerangkan variasi variabel terikat dengan nilai antara nol dan satu. Nilai $R^{2}=0$ berarti variabel bebas tidak memiliki kemampuan dalam menjelaskan variasi variabel terikat dan nilai $R^{2}=1$ berarti variabel bebas memiliki kemampuan dalam menjelaskan variasi variabel terikat.

\section{Pengujian Hipotesis Secara Simultan (Godness of Fit ) (Uji F)}

Menurut Ghozali (2013:98) Uji statistic F menunjukkan apakah semua variabel independen mempunyai pengaruh secara bersama-sama terhadap variabel dependen (terikat). Kriteria yang digunakan dalam Uji F sebagai berikut:

$F_{\text {hitung }}>F_{\text {tabel }}$, maka $H_{a}$ diterima dan $H_{0}$ ditolak

$F_{\text {hitung }}<F_{\text {tabel }}, H_{a}$ ditolak dan $H_{0}$ diterima

\section{Pengujian hipotesis secara parsial (uji t)}

Menurut Ghozali (2013:98) uji statistik t menunjukkan seberapa jauh pengaruh satu variabel independen secara individual dalam menerangkan variabel dependen. Kriteria Uji t dalam penelitian sebagai berikut:

$-t_{\text {tabel }} \leq-t_{\text {hitung }} \leq t_{\text {tabel }}$ maka

$H_{0}$ diterima dan $H_{a}$ ditolak

$-t_{\text {hitung }} \leq-t_{\text {tabel }}$ atau $t_{\text {hitung }}>t_{\text {tabel }}$ maka $H_{0}$ ditolak dan $H_{a}$ diterima.

\section{ANALISIS DAN PEMBAHASAN}

Statistik deskriptif dalam penelitian sebagai berikut: Statistik deskriptif dalam penelitian ini menjelaskan nilai minimum, maksimum, mean dan standar deviasi untuk kelima variabel. Volume Perdagangan saham memiliki nilai minimum 200.000 lembar saham, dan maksimum 25.279.000.000 lembar saham. Nilai mean pada volume perdagangan saham sebesar 1,78E9 dan standar deviasi 4,415E9.

Nilai mean < dengan nilai standar deviasi mengindikasikan bahwa data tidak berdistribusi normal, sehingga memerlukan transformasi data. Indeks harga saham gabungan memiliki nilai minimum 4593,01 dan nilai maksimum 6355,65. Nilai Mean Indeks harga saham gabungan 5.4151E3 dan nilai standar deviasi 730. 88946. Nilai mean $>$ Nilai standar deviasi menunnjukkan data berdistribusi normal. Bid-ask spread memiliki nilai minimum -2.00 dan maksimum 2.00. Nilai Mean 0.369461 dan nilai standar deviasi 0.8101344 . Nilai Mean < Nilai standar deviasi menunjukkan data tidak berdistribusi normal, memerlukan transformasi data. Harga Saham memiliki nilai mnimum Rp. 50, dan nilai maksimum Rp. 8500, dengan nilai mean Rp. 1044.02 dan nilai standar deviasi 1664.490. Nilai mean $<$ Nilai standar deviasi menunjukkan data tidak berdistribusi normal.

\section{Uji Asumsi klasik}

Uji Nornalitas

Uji normalitas dalam penelitian ini menggunakan one sample kolmogurov smrino. Sampel penelitian sebanyak 57 sampel, namun dikarenakan data ada yang tidak berdistribusi normal maka dilakukan transformasi data melalui Logaritma Natural (Ln). Setelah dilakukan transformasi data sampel menjadi 55, dengan nilai Signifikansi $>0,05$. Tabel 4 dapat dilihat bahwa nilai Signifikansi nya 0,974 , dimana nilai signifikansinya $0.974>0,05$, dapat dinyatakan data berdistribusi normal. Selain dari uji One sample kolmogrov smirnov, uji normalitas dapat dilihat dari gambar p-plot. Dari gambar plot mennjukkan pola mengikuti garis diagonal sehingga dapat dikatakan data berdistribusi normal. 
Tabel 3

Statistik Deskriptive

\begin{tabular}{lrrrrr}
\hline \hline & N & Minimun & Maximum & \multicolumn{1}{c}{ Mean } & Std. Deviation \\
\hline Volume Perdagangan & 57 & 200000 & 25279000000 & $1.78 \mathrm{E} 9$ & $4.416 \mathrm{E} 9$ \\
IHSG & 57 & 4593.01 & 6355.65 & $5.4151 \mathrm{E} 3$ & 730.88946 \\
Bid Ask spread & 57 & -2.0000 & 2.0000 & .369461 & .8101344 \\
Harga Saham & 57 & 50 & 8500 & 1044.02 & 1664.490 \\
Valid N (listwise) & 57 & & & & \\
\hline
\end{tabular}

Sumber: Data diolah (2019).

Tabel 4

One-Sample Kolmogorov-Smirnov Test

\begin{tabular}{llr}
\hline & & $\begin{array}{c}\text { Unstandardized } \\
\text { Residual }\end{array}$ \\
\hline $\mathrm{N}$ & & 55 \\
Normal & Mean & .0000000 \\
Parameters & \\
& Std. & 1.03195556 \\
Most & Deviation & .065 \\
Extreme & Absolute & Positive \\
Differences & Negative & .065 \\
Kolmogorov-Smirnov Z & .044 \\
Asymp. Sig. (2-tailed) & .483 \\
\hline
\end{tabular}

Sumber: Data diolah (2019).

Normal P-P Plot of Regression Standardized Residual

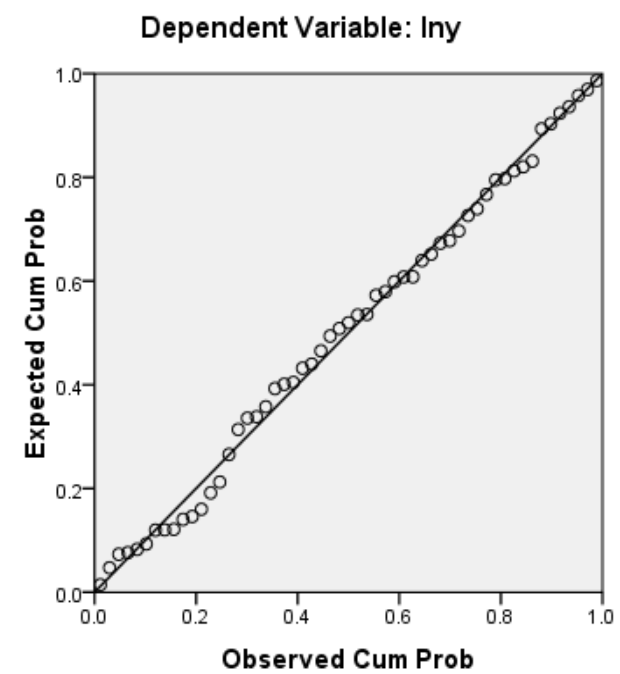

Gambar 2

Uji p-plot

\section{Uji Multikolinieritas}

Uji Multikolinieritas dilihat dari nilai VIF dan Tolerance. Dalam pengujian tidak terjadi multikolinieritas apabila Nilai Tolerance $>0,10$ dan VIF $<10$. Dari Tabel 5 menunjukkan Nilai Tolerance Ln Volume Perdagangan $0,880>0,10$ dan VIF 1,137< 10, Nilai Tolerance Ln Indeks Harga Saham Gabungan 0,969>0,10 dan VIF 1,032 < 10 dan Tolerance Ln Bid Ask Spread 0,905 > 0,10 dan VIF $1,105<10$ sehingga dapat disimpulkan tidak terjadi Multikolinieritas.

Tabel 5

Uji Multikolinieritas

\begin{tabular}{lcc}
\hline \hline \multicolumn{1}{c}{ Variabel } & Tolerance & VIF \\
\hline $\begin{array}{l}\text { Ln Volume } \\
\text { Perdagangan }\end{array}$ & .880 & 1.137 \\
$\begin{array}{l}\text { Ln Indeks } \\
\text { Harga Saham }\end{array}$ & .969 & 1.032 \\
$\begin{array}{l}\text { Gabungan } \\
\text { LnBid Ask }\end{array}$ & .905 & 1.105 \\
Spread & & \\
\hline Sumber: Data diolah (2019). &
\end{tabular}

\section{Uji Heteroskedastisitas}

Uji Heteroskedasritas menggunakan Scatterplot dan Uji Glejser. Dari pengujian ini menunjukkan uji glejser dari setiap variabel nilai sginifikansi nya diatas $>0,05$. Variabel LnVP nilai signifikansi 0,197>0,05. LnIHSG Nilai signifikansi 0,809>0,05 dan variabel Ln Bid-Ask Spread nilai signifikansi nya $0,052>0,05$. Dari hasil penelitian maka tidak terjadi heteroskedastisitas. 
Tabel 6

Uji Glejser

\begin{tabular}{lrc}
\hline \multicolumn{1}{c}{ Model } & \multicolumn{1}{c}{ R } & Sig. \\
\hline Ln Volume Perdagangan Saham & 1.307 & .197 \\
Ln Indeks Harga Saham & .242 & .809 \\
Gabungan & 1.991 & .052 \\
Ln Bid Ask Spread & &
\end{tabular}

Selain Uji Glejser, uji heteroskedastisitas juga dilihat dari scaterplot. Dari gambar scaterplot menunjukkan bahwa titik-titik menyebar tidak membentuk suatu pola dan menyebar di atas dan di bawah angka 0 pada sumbu $Y$, maka dapat disimpulkan tidak terjadi heteroskedastisitas.

Scatterplot

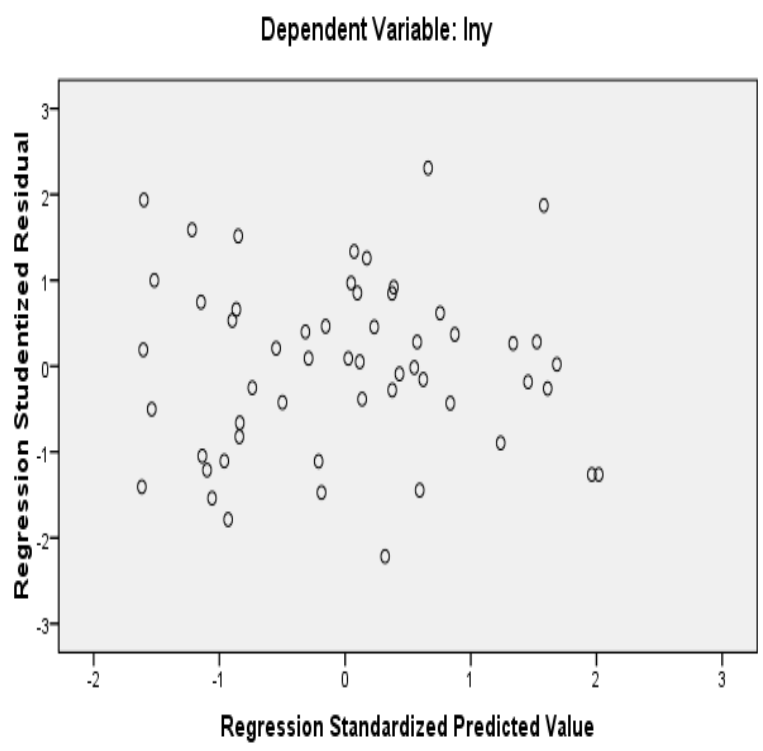

Gambar 3

Scaterplot

\section{Uji Autokorelasi}

Uji autokorelasi menggunakan Runs Test. Untuk uji autokorelasi dinyatakam tidak terjadi autokorelasi jika nilai signifikansinya $>0,05$. Hasil pengujian Runs Test di Tabel 6 menunjukkan nilai Signifikansi 0,494 >0,05 sehingga tidak terjadi autokorelasi.
Tabel 7

Uji Autokorelasi (Runs Test)

\begin{tabular}{lr}
\hline \hline & Unstandardized Residual \\
\hline Test Value & .05203 \\
Cases $<$ Test Value & 27 \\
Cases $>=$ Test Value & 28 \\
Total Cases & 55 \\
Number of Runs & 31 \\
Z & .683 \\
Asymp. Sig. (2-tailed) & .494 \\
\hline
\end{tabular}

Sumber: Data diolah (2019).

\section{Analisis Data}

Analisis data dalam penelitian ini menggunakan analisis regresi linear berganda. Persamaan regresi Linear Berganda sebagai berikut:

Tabel 8

Analisis Data

\begin{tabular}{lcc}
\hline Variabel & B & $\mathbf{t}$ \\
\hline Constant & .020 & .002 \\
Ln Volume Perdagangan & -.187 & -3.724 \\
Ln Indeks Harga Saham & 1.088 & 1.000 \\
Gabungan & & \\
lnBid Ask Spread & -.114 & -1.417 \\
\hline
\end{tabular}

Sumber: Data diolah (2019).

Persamaan Regresi Linear Berganda:

$$
Y=a+b_{1} x_{1}+b_{2} x_{2}+b_{3} x_{3}+e
$$

LnHarga Saham $=0,020-0,187$ LnVolume Perdagangan + 1,088 LnIHSG - 0,114 LnBid-ask Spread

Berdasarkan Tabel 8 dapat diinterprestasikan sebagai berikut: 1). Koefisien regresi variabel Volume perdagangan bertanda negatif. Artinya, jika variabel diturunkan, maka variabel Trend pergerakan harga saham meningkat. Asumsi variabel lainnya tidak berubah. 2). Koefisien regresi variabel Indeks Harga Saham Gabungan bertanda positif. Artinya, jika variabel dinaikkan, maka variabel trend pergerakan harga saham juga akan meningkat. Asumsi variabel 
lainnya tidak berubah, 3). Koefisien regresi variabel Bid Ask Spread bertanda negatif. Artinya, jika variabel diturunkan, maka variabel trend pergerakan harga saham juga akan meningkat. Asumsi variabel lainnya tidak berubah.

Pengujian Godness of Fit (Uji F)
Pengujian hipotesis secara simultan menunjukkan Nilai F hitung sebesar 4,705. Dan F tabel dalam penelitian ini 2,79. Hasil penelitian ini menunjukkan bahwa secara simultan Ln volume perdagangan, Ln indeks harga saham gabungan dan Ln bid ask spread berpengaruh secara signifikan

Tabel 9

Uji F

\begin{tabular}{ccccccc}
\hline \hline & Model & Sum of Squares & Df & Mean Square & F & Sig. \\
\hline 1 & Regression & 15.916 & 3 & 5.305 & 4.705 & $.006^{\mathrm{a}}$ \\
& Residual & 57.506 & 51 & 1.128 & & \\
& Total & 73.422 & 54 & & & \\
\hline
\end{tabular}

Sumber: Data diolah (2019).

terhadap trend pergerakan harga saham. Dimana F Hitung $(4,705)>$ F Tabel $(2,79)$ yang artinya Ha diterima, dan Ho ditolak. Volume Perdagangan, Indeks Harga Saham Gabungan dan Bid Ask Spread berpengaruh terhadap harga saham.

Disimpulkan volume perdagangan yang tinggi, dan Indeks Harga Saham Gabungan yang tinggi, serta bid ask spread tinggi akan mempengaruhi pergerakan harga saham. Pergerakan saham naik atau turun tergantung dari informasi yang diterima oleh investor dan pembentukan harga tergantung dari jumlah permintaan dan penawaran saham.

\section{Pengujian Hipotesis Secara Parsial (Uji t)}

Dilihat dari Tabel 10 bahwa variabel Ln Volume Perdagangan nilai t-hitungnya -3 , 724 dan signifikansi 0,000. Nilai t- hitung untuk variabel Ln Indeks Harga Saham Gabungan sebesar 1,000 dan nilai signifikansi 0,322.

Variabel Ln Bid ask spread menunjukkan nilai t-hitung -1,417 dan nilai signifikansi 0,163 .

Tabel 10

Uji $t$

\begin{tabular}{lcccr}
\hline \hline Variabel & B & $\mathbf{t}$ & Sig. & \multicolumn{1}{c}{ Ket } \\
\hline Constant & .020 & .002 & .998 & \\
LnVolume perdagangan & -.187 & -3.724 & .000 & Signifikan \\
Ln Indeks Harga Saham Gabungan & 1.088 & 1.000 & .322 & Tidak Signifikan \\
Ln Bid Ask Spread & -.114 & -1.417 & .163 & Tidak Signifikan \\
\hline Sumber: Data diolah (2019). & & & &
\end{tabular}

Hasil penelitian secara parsial (uji-t) menunjukkan variabel Volume perdagangan (Ln Volume Perdagangan) nilai $-\mathrm{t}$ hitung $-3,724<-$-t tabel $-2,00758$. Dimana jika -t hitung<-t tabel menunjukkan bahwa variabel volume perdagangan berpengaruh 
negatif terhadap trend pergerakan harga saham. Untuk variabel Ln Indeks Harga Saham Gabungan, nilai $\mathrm{t}$ hitung $1,000<\mathrm{t}$ tabel 2,00758, yang artinya bahwa Indeks Harga Saham Gabungan (LnIndeks Harga Saham Gabungan) tidak berpengaruh terhadap trend pergerakan harga saham. Variabel Ln bid ask spread nilai -t hitung $-1,417>$ nilai -t tabel $-2,00758$, artinya variabel bid ask spread (Ln Bid Ask Spread) tidak berpengaruh terhadap trend pergerakan harga saham.

\section{Koefisien Determinasi ( $\left.\mathbf{R}^{2}\right)$}

Koefisien Determinasi $\left(R^{2}\right)$ dengn nilai adjusted $\mathrm{R}$ Square dalam penelitian ini sebesar $17,1 \%$, artinya variabel volume perdagangan, Indeks Harga Saham Gabungan, dan Bid Ask Spread mempengaruhi trend Pergerakan harga saham, sedangkan sisanya sebesar $82,9 \%$ dipengaruhi variabel diluar penelitian.

Tabel 11

\section{Koefisien Determinasi}

\begin{tabular}{llrr}
\hline \hline Model & R & R Square & \multicolumn{2}{c}{$\begin{array}{c}\text { Adjusted R } \\
\text { Square }\end{array}$} \\
\hline 1 & $.466^{\mathrm{a}}$ & .217 & .171 \\
\hline
\end{tabular}

Output SPSS (2019)

\section{Pembahasan}

Volume Perdagangan Saham berpengaruh terhadap trend pergerakan harga saham

Dari Hipotesis 1, secara statistik menunjukkan bahwa $t$ hitung $>\mathrm{t}$ tabel, yang menunjukkan bahwa volume perdagangan saham berpengaruh negatif dan signifikan terhadap trend pergerakan harga saham, hipotesis ini menyatakan bahwa $\mathrm{Ha}$ diterima, Ho ditolak. Dipasar modal biasanya akan menggambarkan kondisi efek yang diperjualbelikan berupa volume perdagangan saham. Volume perdagangan saham merupakan faktor yang mempengaruhi pergerakan saham.

Peningkatan volume perdagangan saham akan meningkatkan permintaan dan penawaran saham. Ketika jumlah per- mintaan akan saham meningkat dibandingkan penawarannya maka jumlah saham yang diperdagangkan meningkat, volume perdagangan saham juga ikut meningkat namun pergerakan harga sahamnya menurun. Sebaliknya jika penawaran saham meningkat, volume perdagangan turun dan pergerakan harga saham nya naik.

Ketika penurunan harga dan peningkatan volume berarti pada masa yang akan datang akan terjadi peningkatan harga dimana reversal tersebut dapat ditunggu dari munculnya nilai transaksi volume dalam jumlah diatas nilai rata-rata volume biasanya (ledakan volume) (Filbert, (2014: 82).

Hasil penelitian ini sejalan dengan penelitian Sandrasari (2010:69). Bahwa volume perdagangan memiliki pengaruh negatif dan sginifikan terhadap pergerakan harga saham. Volume perdagangan mencermin kan informasi yang diterima oleh pelaku pasar. Peningkatan volume perdagangan akan meningkatkan jumlah permintaan dan penawaran pada suatu saham, dan menentukan trend pergerakan harga saham meningkat atau menurun. Hasil penelitian ini sejalan dengan penelitian Abidin, at al. (2016) menyatakan bahwa volume perdagangan saham memiliki pengaruh negatif dan signifikan terhadap harga saham. Penelitian ini tidak Sejalan dengan penelitian Wulandari, et al. (2009) yang menyatakan bahwa volume perdagangan saham tidak berpengaruh terhadap harga saham.

\section{Indeks Harga Saham Gabungan berpe- ngaruh terhadap trend pergerakan saham}

Uji Hipotesis 2, secara satistik menunjukkan bahwa $\mathrm{t}$ hitung $<\mathrm{t}$ tabel yang menunjukkan bahwa variabel Indeks Harga Saham Gabungan tidak berpengaruh terhadap trend pergerakan harga saham, Ha ditolak dan Ho diterima. Indeks Harga Saham Gabungan ini merupakan gabungan keseluruhan transaksi pergerakan harga saham dari semua sekuritas yang tercatat di Bursa Efek Indonesia (BEI). Indeks harga saham gabungan naik maupun turun tidak 
dapat dijadikan alasan akan mempengaruhi pergerakan harga saham. Saham yang aktif diperdagangkan belum menjamin Indeks Harga Saham Gabungan akan naik. Pergerakan harga saham itu bergantung dari jumlah permintaan dan penawaran saham yang diperdagangkan. Hal ini merupakan angka indeks yang diperoleh merupakan indeks keseluruhan, sehingga tidak dapat dijadikan alasan untuk melihat indeks saham gabungan akan mempengaruhi pergerakan harga saham.

Pergerakan Indeks Harga Saham Gabungan menjadi perhatian utama bagi semua investor dikarenakan pergerakan Indeks Harga Saham Gabungan ini akan dapat mempengaruhi sikap investor untuk berinvestasi apakah akan membeli, menahan atau menjual sahamnya. namun indeks harga saham gabungan tidak mempunyai pengaruh khususnya untuk perusahaan subsektor. Dalam Indeks harga saham gabungan dibagi kedalam saham kelas atas dan saham kelas bawah. Saham kelas atas jika terjadi sedikit transaksi maka Pengaruhnya terasa pada Indeks Harga Saham Gabungan, berbeda dengan saham kelas bawah, jika transaksi yang terjadi besar namun efeknya ke Indeks Harga Saham Gabungan tidak terasa. Hal ini menjelaskan bahwa, ndeks Harga Saham Gabungan tidak mempunyai pengaruh terhadap trend pergerakan harga saham.

Penelitian ini tidak konsisten dengan penelitian Parulian, et al. (2013) yang menyatakan bahwa indeks harga saham gabungan berpengaruh terhadap fluktuasi harga saham, dan Penelitian ini sejalan dengan penelitian Samsuar dan Akramunnas (2017) bahwa IHSG tidak berpengaruh terhadap harga saham.

\section{Bid Ask Spread Berpengaruh terhadap Trend Pergerakan Harga Saham}

Uji Hipotesis 3, secara statistik menunjukkan bahwa $\mathrm{t}$ hitung $<\mathrm{t}$ tabel yang menjelaskan bahwa Variabel bid-ask spread tidak berpengaruh terhadap trend pergerakan harga saham. Artinya Ho diterima dan Ha ditolak. Bid ask spread tidak berpengaruh terhadap trend pergerakan harga saham dikarenakan variabel ini lebih memfokuskan pada perdagangan saham yang aktif dan likuid, tanpa mempengaruhi pergerakan harga saham. Hal lainnya karena variabel ini merupakan selisih dari harga jual dikurangi harga beli saham. Jika permintaan saham akan naik, belum mencerminkan harga jual naik, atau sebaliknya. Jika permintaan saham turun, maka harga jual turun. Hal ini berkaitan dengan interaksi pembeli dan penjual dalam menanggapi kondisi pasar. Hasil penelitian ini sejalan dengan penelitian Abidin, et al. (2016), volume bid tidak berpengaruh terhadap harga saham. Hasil penelitian nya menjelaskan bahwa volume bid dan volume ask yang mengalami kenaikan maupun penurunan tidak mempengaruhi trend pergerakan harga saham, sehingga tidak akan mempengaruhi jumlah permintaan dan penawaran atas saham.

Bid-ask spread yang tinggi akan menghasilkan potensi keuangan yang lebih besar, namun bid-ask spread yang tinggi akan mengakibatkan saham yang diperdagangkan menjadi kurang aktif. Artinya Harga saham mengalami kenaikan dilihat dari jumlah saham yang aktif diperdagangkan, jika selisih nilai harga jual dan harga beli besar maka tidak likuid saham tersebut. Investor lebih menyukai nilai selisih harga jual dan harga beli kecil karena akan menghasilkan tingkat keuntungan. Investor lebih mengharapkan keuntungan dari investasi yang dilakukan. Bid Ask Spread tidak berpengaruh dikarenakan perubahan jumlah permintaan dan penawaran saham yang dibeli tidak membuat pergerakan harga saham naik maupun turun. Faktor penilaian investor juga tidak menyebabkan pergerakan harga saham.

\section{SIMPULAN, DAN SARAN Simpulan}

Simpulan dalam penelitian ini adalah dalam pengujian parsial (uji t) Volume Perdagangan saham secara parsial berpe- 
ngaruh negatif dan signifikan terhadap trend pergerakan harga saham. Variabel Indeks Harga Saham Gabungan (IHSG), secara parsial tidak berpengaruh terhadap trend pergerakan harga saham dan Variabel Bid Ask Spread secara parsial tidak berpengaruh terhadap trend pergerakan harga saham. Pengujian Godness of Fit (Uji- F) volume perdagangan saham, Indeks Harga Saham Gabungan (IHSG), dan Bid Ask Spread berpengaruh terhadap trend pergerakan harga saham. Koefisien determinasi dalam penelitian ini sebesar $17,1 \%$ variabel volume perdagangan, Indeks Harga Saham Gabungan dan bid-ask spread berpengaruh terhadap trend pergerakan harga Saham, sisanya $82,9 \%$ dipengaruhi variabel lain diluar penelitian. Keterbatasan dalam penelitian, jumlah variabel penelitian hanya melihat dari 3 faktor analisis teknikal, yaitu volume perdagangan saham, indeks harga saham gabungan dan bid ask spread. Variabel dependen yang digunakan trend pergerakan harga saham. Tahun pengamatan penelitian hanya 3 tahun yaitu tahun 2015, 2016 dan tahun 2017. Perusahaan yang menjadi sampel adalah perusahaan sub sektor hotel, restoran dan pariwisata. Analisis data menggunakan analisis regresi linear berganda.

\section{Saran}

Saran untuk penelit selanjutnya diharapkan menggunakan faktor-faktor analisis teknikal lainnya, berupa grafik dan chart, serta frekuensi perdagangan dan harga saham masa lalu dan variabel teknikal lainnya dalam menganalisis trend pergerakan harga saham. Peneliti selanjutnya diharapkan menambah tahun pengamatan, serta memilih sampel perusahaan yang lebih luas. Untuk investor, sebelum melakukan investasi sebaiknya membuat pertimbangan-pertimbangan khusus, terutama ketika pengambilan keputusan baik dalam membeli ataupun menjual saham. Analisis teknikal terhadap trend pergerakan harga saham dapat dijadikan sebagai analisis dengan menggunakan harga saham historis sehingga tidak salah dalam melakukan investasi. Pertimbangan khusus yang dilakukan dengan mengikuti trend pergerakan saham yang diwakili banyaknya permintaan maupun penawaran akan saham tersebut. Investor harus dapat mampu memahami variabel analisis teknikal agar dapat menghasilkan tingkat pengembalian (return) atas investasinya. Bagi perusahaan, manajemen dapat mengawasi perilaku investor dalam berinvestasi.

\section{DAFTAR PUSTAKA}

Abidin, S., Suhadak dan R. Hidayat. 2016. Pengaruh faktor-faktor teknikal terhadap harga saham M (Studi Pada Harga Saham IDX30 di Bursa Efek Indonesia Periode Tahun 2012-2015). Jurnal Administrasi Bisnis 37(1): Agustus 2016.

Arifannisa, W. dan A. A. Nugraha. 2017. Pengaruh Faktor-Faktor Fundamental dan Faktor-Faktor Teknikal Terhadap Harga Saham (Studi Empiris pada perusahaan Manufaktur Sektor Industri Barang Konsumsi yang Terdaftar di Bursa Efek Indonesia Periode 20132015. Prosiding. Profesionalisme Akuntan Menuju Sustainable Business Practice.

Akhmadi, dan A. R. Prasetyo. 2018. Profitabilitas, Rasio Solvabilitas dan Harga Saham; Studi Empirik Pada Perusahaan Subsektor Batubara yang terdaftar di Bursa Efek Indonesia Periode 2010-2014. Jurnal Riset Akuntansi Terpadu 11(1): 61-71.

Anwar, F. dan N Asandimitra. 2014. Analisis Perbandingan Abnormal return, Trading Volume Activity, dan Bid Ask Spread sebelum dan sesudah stock split. Jurnal Bisnis dan Manajemen $7(1)$.

Aprilia, Z. 2015. Faktor-Faktor yang Mempengaruhi Bid-Ask Spread Saham LQ45 di Bursa Efek Indonesia. Journal of Research in Economics and Management 15(2): 396-407. 
Bidiosta, Sappar, Suhadak, R. Hidayat. 2015. Analisis Pengaruh Faktor-Faktor Fundamental dan Teknikal Terhadap Nilai Perusahaan. Jurnal Administrasi Bisnis 24(1): 1-10.

Darwis, S. 2013. Pengaruh Volume Perdagangan Terhadap Return Saham LQ45 Selama Bulan Ramadhan di BEI, Jurnal Jurusan Manajemen, STIE MDP, Diakses 29 September 2016, dari www. eprints.mdp.ac.id.

Dewi, Ni Made Ayu Krisna dan I Gst Ngr Agung Suryana. 2016. Volume Perdagangan Saham, Leverage, Tingkat Suku Bunga Terhadap Volatilitas Har ga Saham. E-Jurnal Akuntansi Universitas Udayana 17(2): 1112-1140.

Filbert, R. 2016. Trading Vs Investing. Gramedia Elex Media Komputindo Kompas. Jakarta.

Ghozali, I. 2013. Aplikasi analisis multi variat dengan program SPSS. Badan Penerbit Universitas Diponegoro. Semarang.

Hidayat, T. 2010. Buku Pintar Investasi Reksa Dana, Saham, Opsi Saham, Valas \& Emas. Media Kita. Jakarta.

Halim, A. 2015. Analisis Investasi dan Aplikasinya. Salemba Empat. Jakarta.

Halim, A. dan N. Hidayat. 2010. Studi Empiris Tentang Pengaruh Volume Perdagangan dan Return Terhadap BidAsk Spread Saham Industri Rokok di BEJ dengan Model Korelasi Kesalahan. Jurnal Riset Akuntansi Indonesia (3): 6985.

Jogiyanto. 2013. Teori Portofolio dan Analisis investasi. Edisi Kedelapan. BPFE. Yogyakarta.

Kasim, M. Y. 2010. Prngaruh Indeks harga saham regional terhadap Indeks Harga Saham Gabungan di Bursa Efek Indonesia. Media Litbang Sulteng III, No. I, 27-32, Mei 2010.

Lestari, D. A. 2014. Analisis Perbandingan Abnormal Return dan Volume Perdagangan Saham Sebelum dan Setelah Merger dan Akuisisi. Skripsi. Universitas Diponegoro.
Mie, M. dan Agustina. 2014. Analisis Pengaruh Indeks Harga Saham Gabungan Asing terhadap Indeks Harga Saham Gabungan Indonesia. Jurnal Wira Ekonomi Mikroskil 4(02).

Mutmainah, dan S. Sulasmiyati. 2017. Analisis Teknikal Indikator Stochastic Oscillator dalam menentukan sinyal beli dan sinyal jual saham (studi pada sub sektor konstruksi dan bangunan di bursa efek indonesia periode 2014-2016. Jurnal Administrasi Bisnis (JAB) 49(1).

Ong, E. 2016. Technical Analysis for Mega Profit (Edisi Kedelapan). Grameda Pustaka Utama. Jakarta.

Parulian, Y. H., Betty S. dan Riaman. 2013. Analisis pengaruh IHSG, Inflasi, BI Rate dan Niai Tukar terhadap Fluktuasi Harga Saham Bank di Indonesia. Jurnal Matematika Integratif 9(1): 19-27.

Perdana, M. A., dan Farida T. K. 2014. Pengaruh Varian Return, Harga Saham, Volume Perdagangan, Earning Per Share Terhadap Bid-Ask Spread Saham Syariah (Studi Empiris Pada Perusahaan Yang Terdaftar Pada Jakarta Islamic Index Tahun 2010-2012). E-Journal.

Rahayu, S. S. 2017. Analisis Teknikal Harga Saham pada perusahaan farmasi yang terdaftar di Bursa Efek Indonesia Periode 2015. Agregat. Jurnal Ekonomi dan Bisnis 1(1).

Sandrasari, W. T. 2010. Analisis pengaruh volume Perdagangan, frekuensi perdagangan, dan order imblance terhadap Volatilitas harga saham pada perusahaan go Public di Bursa Efek Indonesia. Skripsi: Universitas Sebelas Maret.

Samsuar, T. dan Akramunnas. 2017. Pengaruh Faktor Fundamental dan Teknikal Terhadap Harga Saham Industri Perhotelan Yang terdaftar di Bursa Mashrafiyah. Jurnal Ekonomi, Keuangan dan Perbankan Syariah 1(1): 116-131.

Santoso, F. P. 2018. Pengaruh Frekuensi Perdagangan, harga saham masa lalu dan volume perdagangan saham terhadap harga saham IDX30. Skripsi. 
Sekolah Tinggi Ilmu Ekonomi Perbanas. Surabaya.

Susanto, D. dan S. Agus. 2010. Analisis Teknikal di Bursa Efek. Edisi Dua. UPP STIM YKPN. Yogyakarta.

Utomo, S. 2016. Trading Saham dengan Menggunakan Fibonacci Retracement. Gramedia. PT. Elex Media Komputindo. Jakarta.

Wulandari, D., Sumiaty dan H. Susanto. 2009. Analisis Pengaruh Variabelvariabel fundamental dan teknikal terhadap harga saham (studi pada industri tekstil yang go public di bursa efek jakarta). Wacana 12(3).

Zulkarnaen, A. H. 2017. Pengaruh FaktorFaktor Fundamental dan Teknikal
Terhadap Harga Saham Pada Industri Property Real Estate di BEI. Tesis. Sekolah Pascasarjana. Institut Teknologi Bogor.

Sofia, H. dan R. Burhani. .2014. Investasi terbesar pariwisata dibidang hotel restoran. https://www.antaranews. com/berita/427196/investasi-terbesarpariwisata-bidang-hotel-restoran. diakses tanggal 29 September 2018.

Syifa, P. N dan Sakina R.D.S. 2018. Hotel dan Restoran jadi Investasi Favorit Pariwisata. https://ekonomi.kompas.com/ $\mathrm{read} / 2018 / 09 / 27 / 091635126 /$ hotel-dan -restoran-jadi-investasi-favorit-untukpariwisata. diakses tanggal 27 September 2018. 